\title{
Self-Reflection and Insight pada Mahasiswa Kedokteran dan Hubungannya dengan Persepsi terhadap Perilaku Profesional
}

\author{
Shulhana Mokhtar*, Ova Emilia**, Efrayim Suryadi** \\ * Fakultas Kedokteran UMI, Makasar \\ ** Program Studi S2 IImu Pendidikan Kedokteran Fakultas Kedokteran Universitas Gadjah Mada
}

\begin{abstract}
Background: In term of health service duty, physicians unprofessional behavior, than their lack of knowledge or skills, are more likely to couse some problem. The issues of proffesionalism can be identified when student are still in the process of education. There are several things associated with the development of professionalism, such as self-reflection and the ability to understand (insight) the incidents around them in this study proffesional behavior was mainly connected with responsibility.

Objective: This study aimed to examined the relationsheps betwen UMI medical students (SRI) and perception of professionalism (responsibility)

Methods: It is a quantitative study using cross sectional approach. The participants were UMI students of batch 2009 . 2011 who are still studying at the university data were obtained from the questionnaires SRI scale and perceptions scale. Descriptive statistics, $t$-test and ANOVA-test and Pearson correlation test were used to analyze the data.

Results and Discussion: In general, students SRI score were LOW $(M=2,46)$, as well as students' perceptions of responsible behavior $(M=2,25)$. Based on students characteristics, significant difference in SRI was only found in the high school of origin $(p=0,043)$ and in the perception was found in father's occupation $(p=0,018)$. Correlation analysis found a significant relationship between SRI and perceptions of professionalism ( $p=0,0001)$.

Conclusion: Self-reflection and insight of UMI medical students were still low and they were aligned with students' perceptions of professional conduct (responsibility) which were also low. These values varied by students characteristics but for all intents and purposes, the differences were not significant.
\end{abstract}

Keywords: self-reflection, insight, perception of professional behavior

\section{ABSTRAK}

Latar Belakang: Berkaitan dengan tugas pelayanan kesehatan, diindikasikan bahwa kebanyakan masalah muncul bukan karena kurangnya pengetahuan atau minimnya keterampilan yang dimiliki seorang dokter namun lebih karena adanya perilaku yang tidak profesional. Masalah berkaitan perilaku profesional kemungkinan besar teridentifikasi pada saat seorang dokter masih menjalani proses pendidikan sebagai mahasiswa kedokteran. Ada beberapa hal yang dapat dikaitkan dengan perkembangan perilaku profesional, di antaranya adalah refleksi diri dan kemampuan untuk memahami apa yang terjadi di sekitarnya. Perilaku mahasiswa yang merefleksikan profesionalisme yang paling banyak disorot adalah perilaku bertanggung-jawab.

Tujuan: Penelitian ini menguraikan gambaran self-reflection and insight (SRI) pada mahasiswa kedokteran, gambaran persepsi mahasiswa terhadap perilaku profesional (bertanggung-jawab) dan menganalisis hubungan di antara keduanya.

Metode: Penelitian ini adalah penelitian kuantitatif dengan rancangan cross sectional. Subjek penelitian adalah mahasiswa yang masih aktif saat penelitian berlangsung (angkatan 2009 - 2011). Selain data karakteristik mahasiswa, diperoleh data dari kuesioner berupa skala SRI dan skala persepsi yang terdiri dari 5 skala likert. Data yang diperoleh dianalisis dengan analisis statistik deskriptif, uji beda t-test dan Anova serta uji korelasi Pearson.

Korespondensi: shulma@gmail.com 
Hasil dan Pembahasan: Secara umum gambaran SRI mahasiswa masih rendah dengan skor rata-rata= 2,46, demikian juga dengan persepsi mahasiswa terhadap perilaku bertanggung-jawab (skor rata-rata $=2,25$ ). Berdasarkan karakteristik mahasiswa, perbedaan bermakna pada SRI hanya ditemukan pada asal SMU $(p=0,043)$ dan pada persepsi ditemukan pada pekerjaan ayah $(\mathrm{p}=0,018)$. Hasil uji korelasi menunjukkan adanya hubungan yang cukup antara skor SRI dan skor persepsi $(\mathrm{p}=0,0001)$.

Kesimpulan: Self-reflection dan insight mahasiswa kedokteran FK UMI masih rendah dan hal tersebut selaras dengan persepsi mahasiswa terhadap perilaku profesional (bertanggung-jawab) yang juga rendah. Nilai tersebut berbeda-beda berdasarkan karakteristik latar belakang mahasiswa seperti asal sekolah dan pekerjaan orang tua menentukan perbedaan level SRI dan persepsi terhadap profesionalitas (perilaku professional) namun sebagian besar perbedaan tersebut tidak bermakna.

Kata kunci: self-reflection, insight, persepsi terhadap perilaku profesional

\section{PENDAHULUAN}

Pelayanan kesehatan saat ini sangat membutuhkan dokter yang melakukan praktik kedokteran dengan segenap kompetensinya untuk menghadapi tuntutan masyarakat yang semakin sadar akan hak-haknya di samping kewajiban-kewajiban yang harus mereka penuhi. Ada banyak faktor yang mempengaruhi kompeten tidaknya seorang dokter, salah satu di antaranya adalah bagaimana dia menjalani proses pendidikannya saat kuliah dulu. Ibarat sebuah sungai, pelayanan kesehatan merupakan proses hilir sehingga baik buruknya pelayanan kesehatan ditentukan dari hulu, yaitu pendidikan profesi kedokteran yang menjunjung etika kedokteran.

Pemerintah melalui Konsil Kedokteran Indonesia telah menyusun Standar Kompetensi Dokter Indonesia (SKDI) tahun 2006 (dan diperbaharui tahun 2013) yang bisa digunakan sebagai standar kompetensi dalam pendidikan kedokteran bagi segenap institusi. Hal tersebut bertujuan agar dokter-dokter yang dihasilkan memiliki kompetensi-kompetensi yang sudah ditetapkan. Kompetensi yang dimaksud (menurut SK Mendiknas No. 045/U/2002) adalah 'Seperangkat tindakan cerdas dan penuh tanggung-jawab sebagai syarat untuk dianggap mampu oleh masyarakat dalam melaksanakan tugas-tugas di bidang pekerjaan tertentu'. ${ }^{1}$ Penyusunan standar tersebut tentu pada akhirnya bertujuan untuk meningkatkan kualitas pelayanan kesehatan terhadap masyarakat.
Berkaitan dengan tugas pelayanan tersebut, beberapa dokter diindikasikan gagal dalam menangani pasien mereka karena perilaku yang tidak profesional, bukannya karena pengetahuan yang kurang atau keterampilan klinik yang rendah. Menariknya, dokter yang telah melakukan penyelewengan serius dalam perilaku profesional kemungkinan besar memperlihatkan indikasi awal keadaan ini saat masih kuliah di fakultas kedokteran. $^{2}$

Pihak universitas perlu mengidentifikasi mahasiswa yang rentan terhadap perilaku yang tidak profesional dengan melihatnya melalui perubahan perilaku yang disengaja dan sekarang banyak institusi yang mengembangkan pengukuran yang kompleks tentang profesionalisme dan program-program pendukung, dengan kondisi bahwa prediksi validitasnya akan membutuhkan waktu dan pelaksanaannya bersifat resource-intensive. Keadaan ini menimbulkan pertanyaan apakah ada pengukuran yang lebih mudah dilaksanakan, pertama; bisa memberi laporan kepada perencana perkuliahan tentang kesiapan mahasiswa untuk mengatur sendiri perilaku profesionalnya dan, kedua; mencatat perubahanperubahan kemajuan mereka sepanjang program. ${ }^{3}$

Sampai saat ini masalah-masalah tersebut jumlahnya tidak terdata dengan baik, dan dapat menimbulkan atmosfer akademik yang kurang kondusif di lingkungan kampus. Padahal sebagai seorang calon profesional, dibutuhkan perilaku-perilaku yang ideal termasuk bagaimana mereka dapat memiliki pemahaman yang mendalam dan 
mengaitkannya dengan sifat profesionalitas mereka sendiri.

Penelitian kali ini difokuskan pada pengukuran karakteristik dua faktor metakognitif, yaitu: insight (pemahaman) dan reflection (refleksi/pemikiran). Ada beberapa alasan mengapa kedua hal ini penting dalam perkembangan perilaku profesional. Agar para dokter dapat memelihara dan meningkatkan kemampuan kliniknya, mereka harus memiliki pemahaman yang dalam terhadap masalah-masalah yang mungkin timbul dalam praktik klinik dan mampu menghubungkannya dengan keprofesiannya. ${ }^{3}$
Dalam konteks ini, insight didefinisikan sebagai kesadaran kemampuan dirinya, kesadaran akan kemampuan orang lain dan kecakapannya dalam merefleksikan kedua hal tersebut untuk membuat keputusan. ${ }^{4}$ Selfreflection (refleksi diri) membantu mahasiswa mengintegrasikan teori praktik keprofesian dengan pengalamannya untuk mengembangkan praktik mereka sendiri. ${ }^{5}$

Hubungan antara insight dan reflection dijelaskan dalam konteks teori self-regulation atau regulasi diri oleh Grant. ${ }^{6}$ Kemajuan yang dituju pada siklus regulasi diri melalui pencapaian tujuan-tujuan khusus (gambar 1) bergantung kemampuan seseorang untuk memonitor dan mengevaluasi kemajuannya dan melakukan feedback agar berhasil memperbaiki kinerjanya.
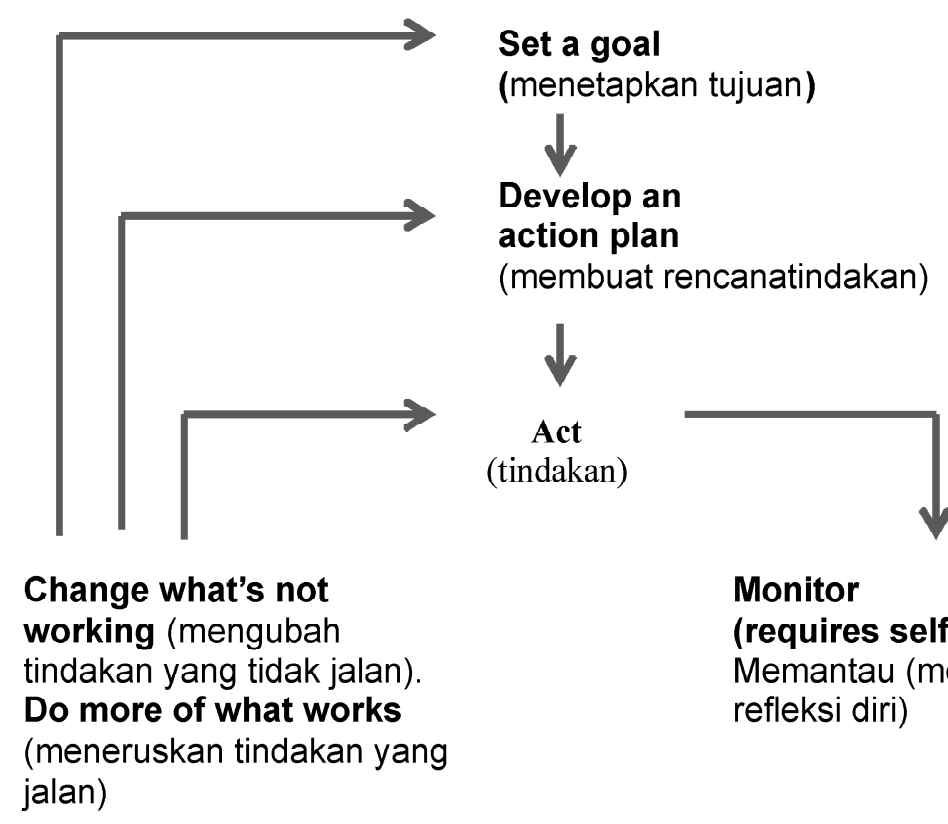

\section{Monitor} (requires self-reflection) Memantau (memerlukan refleksi diri)
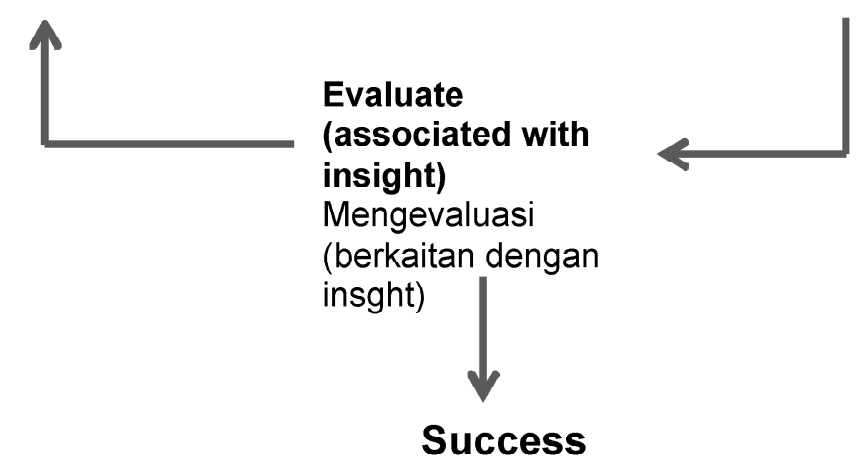

Gambar 1. Gambaran umum self-regulation dan pencapaian tujuan menunjukkan peran self-reflection dan insight (gambar dikembangkan oleh A.M. Grant) 
Dari gambar di atas terlihat bahwa insight dan selfreflection merupakan pusat dari proses regulasi diri. Jadi, mahasiswa yang secara teratur memonitor pikiran, perasaan dan perilakunya seharusnya memiliki tingkat insight dan selfreflection yang lebih tinggi. ${ }^{3}$ Seperti telah dikemukakan di atas, bahwa insight dan self-reflection penting dalam perkembangan perilaku profesional. Schon menyebutkan bahwa perilaku profesional, yang ilmunya bersifat implisit, paling baik dipelajari bukan di ruang kuliah, melainkan dari pembelajaran di sekitar kita yang memunculkan selfreflection dan meningkatkan mindfulness atau reflective practice.

Beberapa perilaku yang merefleksikan profesionalisme, yang disusun dari hasil konferensi Association of American Medical Colleges (AAMC) dan National Board of Medical Examiners (NBME) pada tahun 2003 adalah Altruism, Honor and Integrity, Caring and Compassion, Respect, Responsibility and Accountability, Excelence and Scholarship, Leadership. ${ }^{8}$ Tentu telah diketahui bersama bahwa seseorang tidak bisa dikatakan berperilaku profesional jika hanya ada satu aspek yang muncul karena profesionalisme merupakan suatu kesatuan yang kategorikategorinya tidak terlepas satu sama lain. Namun, berdasarkan hasil temuan sementara terhadap perilaku mahasiswa, ditemukan bahwa perilaku bertanggung-jawab (responsibility) merupakan perilaku yang paling banyak disorot.

Tanggung-jawab adalah kesadaran manusia akan tingkahlaku atau perbuatannya baik yang disengaja maupun yang tidak disengaja. Tanggung-jawab juga berarti berbuat sebagai perwujudan kesadaran akan kewajibannya.? Dalam tulisannya tentang manusia dan tanggung-jawab, Widagdho mengaitkan tanggung-jawab dengan pengabdian (perbuatan baik yang berupa pikiran, pendapat ataupun tenaga sebagai perwujudan kesetiaan), kesadaran (keinsyafan akan perbuatannya) dan pengorbanan (memberikan secara ikhlas baik pikiran, tenaga, waktu dan sebagainya). Hal-hal tersebut berkaitan erat dengan refleksi perilaku profesional sebagaimana yang disusun oleh AAMC dan NBME (2003). ${ }^{5}$

Tujuan penelitian ini menguraikan gambaran self reflection and insight (SRI) pada mahasiswa kedokteran, gambaran persepsi mahasiswa terhadap perilaku profesional (bertanggung jawab) dan menganalisis hubungan diantara keduanya.

\section{METODE}

Penelitian ini menggunakan metode kuantitatif dengan rancangan cross sectional. Subjek penelitian adalah semua mahasiswa FK UMI yang aktif pada saat penelitian berlangsung, yaitu angkatan 2009 - 2011. Jumlah total mahasiswa adalah 452 orang, Tiga puluh orang di antaranya diminta sebelumnya untuk mengisi kuesioner untuk keperluan validasi kuesioner yang digunakan sehingga tidak masuk dalam responden penelitian.

Penelitian ini menggunakan dua buah instrument, lembar kuesioner Self-Reflection and Insight Scale (SRIS) yang telah diterjemahkan ke dalam bahasa Indonesia, dan kuesioner tentang persepsi mahasiswa terhadap perilaku bertanggung-jawab. ${ }^{6,9}$ Kuesioner tersebut disusun oleh penulis berdasarkan kriteria yang dapat dimasukkan dalam kategori perilaku bertanggung-jawab, menurut uraian profesionalisme yang disusun oleh AAMC dan NBME. ${ }^{8}$

Skala self-reflection and insight (SRI) dalam penelitian ini (dikembangkan pertama kali oleh Grant) memiliki 3 komponen yaitu engagement in self-reflection, need for relection dan insight. ${ }^{6}$ Skala ini terdiri dari 20 butir pernyataan yang menggunakan skala Likert. Skor 1 diberikan untuk jawaban sangat tidak setuju hingga skor 5 untuk jawaban sangat setuju pada pernyataan favorable. Skor sebaliknya diberikan untuk pernyataan yang unfavorable. Skor ratarata tertinggi yang bisa dicapai yaitu 5 . Kuesioner ini terdiri dari 12 pernyataan (favorable dan unfavorable) yang menggunakan 5 skala Likert seperti halnya skala SRI, dengan skor 1 untuk jawaban paling randah dan skor 5 untuk jawaban paling tinggi.

Dari 422 kuesioner yang dibagikan, sebanyak 374 kuesioner yang dapat dianalisis. Selanjutnya, data yang terkumpul dimasukkan dan dianalisis menggunakan program SPSS versi 17.

\section{HASIL DAN PEMBAHASAN}

Berdasarkan karakteristik responden, responden terbanyak adalah wanita $(70,1 \%)$, dari tingkat fase akademik yang paling banyak adalah angkatan 2010 $(39,6 \%)$ dan asal SMU responden terbanyak dari luar kota Makassar (mencapai 68,4\%), tabel 1. 
Tabel 1. Distribusi responden berdasarkan jenis kelamin, tingkat dalam fase akademik dan asal SMU

\begin{tabular}{lcc}
\multicolumn{1}{c}{ Karakteristik responden } & Jumlah & Persentease \\
Jenis Kelamin & & \\
- Laki-laki & 112 & 29,9 \\
- Perempuan & 262 & 70,1 \\
Tingkat dalam fase akademik & & \\
- Tingkat I (angkatan 2011) & 92 & 24,6 \\
- Tingkat II (angkatan 2010) & 148 & 39,5 \\
- Tingkat III (angkatan 2009) & 134 & 35,8 \\
Asal SMU & & \\
- Makassar & 118 & 31,6 \\
- Luar Makassar & 256 & 68,4 \\
\hline
\end{tabular}

Suku terbanyak dari responden (mengikuti suku dominan dari ayah) adalah suku Bugis $(63,6 \%)$ dan paling sedikit adalah keturunan Arab/Indo dan NTT/ Flores.

Pendidikan terakhir ayah yang paling banyak adalah D3/S1-Sederajat (41,4 \%) dan paling sedikit adalah SMU/di bawah SMU (26,2 \%). Sedangkan pendidikan terakhir ibu paling banyak juga adalah D3/S1-Sederajat
$(47,6 \%)$ dan paling sedikit adalah S2/S3-Spesialis $(13,1$ \%).

Tabel 2 menyajikan data pekerjaan ayah paling banyak adalah wiraswasta (32,6\%), demikian juga pekerjaan ibu paling banyak adalah wiraswasta $(26,5 \%)$. Lalu jenis pekerjaan ayah paling sedikit adalah pengacara $(0,3 \%)$ sedangkan jenis pekerjaan ibu paling sedikit adalah hakim $(0,5 \%)$.

Tabel 2. Distribusi responden berdasarkan pekerjaan orang-tua

\begin{tabular}{lcc}
\multicolumn{1}{c}{ Pekerjaan orang-tua } & Jumlah & Persentase \\
\hline $\begin{array}{l}\text { Pekerjaan Ayah } \\
\text { - PNS }\end{array}$ & 72 & \\
- Profesional: & & 19,3 \\
- Guru/Dosen & 59 & 15,8 \\
- Dokter/Dosen & 26 & 7,0 \\
- Peg.Kesehatan & 20 & 5,3 \\
- Polisi/TNI & 22 & 5,9 \\
- Pengacara & 1 & 0,3 \\
- Pekerjaan lain & & \\
- Karyawan & 32 & 8,6 \\
- Wiraswasta & 122 & 32,6 \\
- Anggota Dewan & 6 & 1,6 \\
- Lain-lain & 14 & 3,7 \\
\hline
\end{tabular}


Lanjutan tabel 2. Distribusi responden berdasarkan pekerjaan orang-tua

\begin{tabular}{lcc}
\multicolumn{1}{c}{ Pekerjaan orang-tua } & Jumlah & Persentase \\
\hline $\begin{array}{l}\text { Pekerjaan Ibu } \\
\text { - PNS }\end{array}$ & 35 & \\
- Profesional & & 9,4 \\
- Guru/Dosen & 71 & 19,0 \\
- Dokter/Dosen & 19 & 5,1 \\
- Peg. Kesehatan & 42 & 11,2 \\
- Hakim & 2 & 0,5 \\
- Pekerjaan Lain & & \\
- Karyawan & 22 & 5,9 \\
- Wiraswasta & 99 & 26,5 \\
- Pekerjaan lain & 6 & 1,6 \\
- IRT & 78 & 20,9 \\
\hline
\end{tabular}

1. Gambaran SRI pada mahasiswa kedokteran

Tabel 3. Gambaran self-reflection and insight mahasiswa FK UMI

\begin{tabular}{|c|c|c|c|}
\hline Variabel & $\mathbf{n}$ & Skor rata-rata & SD \\
\hline Engagennent in self -reflection & 374 & 2,47 & 0,47 \\
\hline Need for reflection & 374 & 2,04 & 0,45 \\
\hline Insight & 374 & 2,77 & 0,56 \\
\hline SRI & 374 & 2,46 & 0,37 \\
\hline
\end{tabular}

$\mathrm{n}=$ Jumlah responden

$\mathrm{SD}=$ Standar deviasi

SRI = Self-reflection and insight

Pada tabel 3, skor rata-rata SRI adalah 2,46. Dari nilai maksimum 5. Ini berarti nilai skor rata-rata masih di bawah dari nilai tengah skala Likert yang digunakan.
Selain itu dapat dilihat bahwa di antara ketiga variabel SRI, yang paling tinggi adalah insight. 
Gambaran tingkat SRI berdasarkan karakteristik mahasiswa

Tabel 4. Self-Reflection and Insight berdasarkan jenis kelamin dan asal SMU

\begin{tabular}{lccccc}
\multicolumn{1}{c}{ Variabel } & $\mathbf{n}$ & Mean \pm SD & $\Delta$ Mean & $\mathbf{t}$ & $\begin{array}{c}\text { Sig. } \\
\text { (2-tailed) }\end{array}$ \\
$\begin{array}{l}\text { Jenis kelamin } \\
\text { - Laki-laki }\end{array}$ & 111 & $2,42 \pm 0,38$ & $-0,058$ & $-1,374$ & 0,170 \\
- Perempuan & 263 & $2,48 \pm 0,37$ & & & \\
Asal SMU & & & & \\
- Makassar & 118 & $2,52 \pm 0,35$ & 0,084 & 2,035 & 0,043 \\
- Luar Makassar & 256 & $2,43 \pm 0,38$ & & & \\
\hline
\end{tabular}

Pada tabel 4, terlihat bahwa skor rata-rata perempuan lebih tinggi dari skor laki-laki, namun perbedaan tersebut tidak bermakna $(p=0,170)$. Mahasiswa yang asal SMU
Makasar memiliki skor lebih tinggi dibandingkan skor SMU luar Makasar ( $\mathrm{p}<0,005)$.

Tabel 5. Self-reflection and insight berdasarkan tingkat dalam fase akademik, suku dan pendidikan orang-tua

\begin{tabular}{lcccc}
\multicolumn{1}{c}{ Variabel } & n & Mean \pm SD & f & Sig. \\
\hline Tingkat dalam fase akademik & & & & \\
- Tingkat I (angkatan 2011) & & & & \\
- Tingkat II (angkatan 2010) & 92 & $2,48 \pm 0,36$ & 1,879 & 0,154 \\
- Tingkat III (angkatan 2009) & 148 & $2,49 \pm 0,37$ & & \\
& 134 & $2,41+0,38$ & & \\
Suku & & & & \\
- Bugis & 238 & $2,48 \pm 0,36$ & 0,468 & \\
- Makassar & 35 & $2,43 \pm 0,38$ & & \\
- Suku lainnya & 101 & $2,44 \pm 0,40$ & & \\
\hline
\end{tabular}

Demikian juga pada tabel 5. Tidak ada perbedaan bermakna skor SRI pada fase akademik yang berbeda ataupun suku asal yang berbeda. Namun mahasiswa tingkat II dan berasal dari suku bugis memiliki skor SRI lebih tinggi. 
Tabel 6. Self-Reflection and Insight berdasarkan pendidikan dan pekerjaan orang-tua

\begin{tabular}{lcccc}
\multicolumn{1}{c}{ Variabel } & n & Mean \pm SD & f & Sig. \\
Pendidikan Ayah & & & & \\
- SMU/di bawah SMU & 98 & $2,49 \pm 0,39$ & 0,653 & 0,521 \\
- D3/S1-Sederajat & 155 & $2,44 \pm 0,36$ & & \\
- S2/S3-Spesialis & 121 & $2,47 \pm 0,38$ & & \\
Pendidikan Ibu & & & & \\
- SMU/di bawah SMU & 147 & $2,48 \perp 0,36$ & & \\
- D3/S1-Sederajat & 178 & $2,44 \pm 0,40$ & 0,503 & \\
- S2/S3-Spesialis & 49 & $2,46 \perp 0,32$ & & \\
Pekerjaan Ayah & & & & \\
- PNS & 72 & $2,46 ? 0,33$ & 0,078 & \\
- Profesional & 128 & $2,45 ? 0,35$ & & \\
- Pekerjaan lain & 174 & $2,47 ? 0,41$ & & \\
Pekerjaan Ibu & & & & \\
- PNS & 35 & $2,41 ? 0,35$ & 0,815 & \\
- Profesional & 134 & $2,44 ? 0,38$ & & \\
- Pekerjaan lain & 127 & $2,47 ? 0,38$ & & \\
- IRT & 78 & $2,51 ? 0,36$ & & \\
\hline
\end{tabular}

Dilihat dari latar belakang keluarga, tabel 6 menunjukkan bahwa skor SRI tidak menunjukkan perbedaan bermakna pada mahasiswa dengan pendidikan dan pekerjaan orang tua, berbeda $(\mathrm{p}>0,05)$.

2. Gambaran persepsi mahasiswa terhadap perilaku bertanggung-jawab

Tabel 7. Persepsi mahasiswa terhadap perilaku bertanggung-jawab

\begin{tabular}{|c|c|c|c|}
\hline Variabel & $\mathbf{n}$ & Skor rata-rata & SD \\
\hline Tanggung-jawab terhadap tugas & 374 & 2,21 & 0,55 \\
\hline Tanggung-jawab terhadap orang & & & \\
\hline lain & 374 & 2,57 & 0,57 \\
\hline $\begin{array}{l}\text { Tanggung jawab terhadap diri } \\
\text { sendiri }\end{array}$ & 374 & 2,09 & 0,49 \\
\hline Total persepsi* & 374 & 2,25 & 0,40 \\
\hline
\end{tabular}

Pada tabel 7 di atas, dapat dilihat bahwa skor rata-rata untuk total persepsi adalah 2,25. Hal ini menunjukkan bahwa skor rata-rata total persepsi masih di bawah nilai tengah skala Likert yang digunakan. Selain itu dapat dilihat juga bahwa di antara ketiga variabel persepsi, yang paling tinggi adalah skor tanggung-jawab terhadap orang lain. 
Gambaran persepsi berdasarkan karakteristik mahasiswa

Tabel 8. Gambaran persepsi mahasiswa berdasarkan jenis kelamin dan asal SMU

\begin{tabular}{lccccc}
\multicolumn{1}{c}{ Variabel } & $\mathbf{n}$ & Mean \pm SD & $\Delta$ Mean & t & $\begin{array}{c}\text { Sig. } \\
\text { (2-tailed) }\end{array}$ \\
$\begin{array}{l}\text { Jenis kelamin } \\
\text { - Laki-laki }\end{array}$ & 111 & $2,28 \pm 0,44$ & 0,055 & 1,138 & 0,257 \\
- Perempuan & 263 & $2,23 \pm 0,38$ & & & \\
$\begin{array}{l}\text { Asal SMU } \\
\text { - Makassar }\end{array}$ & 118 & $2,28 \pm 0,38$ & 0,048 & 1,076 & 0,282 \\
- Luar Makassar & 256 & $2,23 \pm 0,40$ & & & \\
\hline
\end{tabular}

Pada tabel 8, persepsi mahasiswa tidak berbeda pada laki-laki dan perempuan, juga tidak berbeda antara mahasiswa yang bersal dari SMU Makasar atau luar Makasar.

Dalam tabel 9, selanjutnya diuraikan tentang hasil analisis persepsi mahasiswa berdasarkan tingkat dalam fase akademik, suku, pendidikan dan pekerjaan orang-tua.
Persepsi perilaku bertanggung jawab tidak berbeda pada fase akademik, suku pendidikan ayah dan pekerjaan ibu yang berbeda. Terdapat beda bermakna, meskipun secara praktis tidak ada, antara persepsi mahasiswa pada pekerjaan ayah yang berbeda $(p<0,005)$

Tabel 9. Persepsi perilaku bertanggung jawab berdasarkan tingkat dalam fase akademik, suku, pendidikan dan pekerjaan orang-tua

\begin{tabular}{lcccc}
\multicolumn{1}{c}{ Variabel } & n & Mean \pm SD & f & Sig. \\
\hline Tingkat dalam fase akademik & & & & \\
- Tingkat I (angkatan 2011) & & & & \\
- Tingkat II (angkatan 2010) & 92 & $2,27 \pm 0,37$ & 2,265 & 0,105 \\
- Tingkat III (angkatan 2009) & 148 & $2,20 \pm 0,38$ & & \\
& 134 & $2,29 \pm 0,42$ & & \\
Suku & & & & \\
- Bugis & 238 & $2,25 \pm 0,40$ & 2,246 & 0,107 \\
- Makassar & 35 & $2,38 \pm 0,45$ & & \\
- Suku lainnya & 101 & $2,21 \pm 0,37$ & & \\
Pendidikan Ayah & & & & \\
- SMU/di bawah SMU & 98 & $2,30 \pm 0,41$ & 1,009 & 0,366 \\
- D3/S1-Sederajat & 155 & $2,22 \pm 0,38$ & & \\
- S2/S3-Spesialis & 121 & $2,24 \pm 0,41$ & & \\
Pendidikan Ibu & & & & \\
- SMU/di bawah SMU & 147 & $2,30 \pm 0,41$ & 3,013 & 0,050 \\
- D3/S1-Sederajat & 178 & $2,20 \pm 0,39$ & & \\
- S2/S3-Spesialis & 49 & $2,29 \pm 0,35$ & & \\
Pekerjaan Ayah & & & & \\
- PNS & 72 & $2,14 ? 0,38$ & 4,034 & 0,018 \\
- Profesional & 128 & $2,24 ? 0,36$ & & \\
- Pekerjaan lain & 174 & $2,30 ? 0,42$ & & \\
Pekerjaan Ibu & & & & \\
- PNS & 35 & $2,18 ? 0,40$ & 1,493 & 0,216 \\
- Profesional & 134 & $2,21 ? 0,36$ & & \\
- Pekerjaan lain & 127 & $2,29 ? 0,42$ & & \\
- IRT & 78 & $2,28 ? 0,42$ & & \\
\hline
\end{tabular}




\section{Hubungan antara SRI dan persepsi terhadap} perilaku bertanggung-jawab

Selanjutnya dilakukan analisis bivariat untuk melihat hubungan antara level SRI dan persepsi mahasiswa terhadap perilaku bertanggung-jawab dengan menggunakan analisis Pearson's correlation. Berdasarkan hasil uji tersebut di atas, didapatkan hasil nilai $\mathrm{p}<0,01$ dengan koefisien korelasi sebesar 0,362. Hal ini menunjukkan bahwa terdapat hubungan yang bermakna antara level SRI dan persepsi mahasiswa terhadap perilaku bertanggung-jawab.

Dari hasil analisis data yang telah dilakukan, terlihat bahwa terdapat hubungan yang bermakna antara level SRI dan persepsi mahasiswa terhadap perilaku bertanggung-jawab. Hal ini sesuai dengan hipotesis penelitian yang dikemukakan peneliti dalam awal penelitian.

Gambaran self-reflection and insight mahasiswa kedokteran FK UMI menunjukkan skor rata-rata sebesar 2,46. Nilai ini masih di bawah nilai tengah skala Likert yang digunakan (kuesioner dalam penelitian ini menggunakan 5 skala Likert dengan nilai tengah skala adalah 2,5). Hasil tersebut mengindikasikan bahwa kemampuan mahasiswa FK UMI untuk memonitor pikiran, perasaan dan perilakunya masih di bawah rata-rata. ${ }^{3}$ Bahwa mahasiswa yang secara teratur memonitor pikiran, perasaan dan perilakunya seharusnya memiliki tingkat insight dan selfreflection yang lebih tinggi. Refleksi diri akan membantu mahasiswa untuk mengintegrasikan teori praktik professional dengan pengalaman mereka untuk mengembangkan metode praktik mereka sendiri. ${ }^{5}$ Namun demikian, masih terlalu dini untuk mengatakan bahwa responden kelak tidak dapat mengembangkan metode praktiknya karena rendahnya nilai SRI yang didapatkan.

Pada penelitian ini, didapatkan hasil nilai rata-rata skor persepsi mahasiswa terhadap perilaku bertanggung-jawab sebesar 2,25. Nilai ini juga berada di bawah nilai tengah skala Likert yang digunakan. Hal ini menunjukkan bahwa mahasiswa FK UMI memiliki persepsi yang rendah terhadap perilaku bertanggung-jawab baik itu terhadap tugas, terhadap orang-lain maupun terhadap diri sendiri.
Penelitian tentang selfreflection and insight menunjukkan bahwa skala SRI ini berguna untuk memperkirakan kesiapan mahasiswa dalam mengembangkan perilaku profesional sepanjang program pendidikan kedokteran. ${ }^{3}$ Hal tersebut terlihat pada perbedaan hasil skor SRI yang didapatkan pada setiap situasi yang berbeda. Namun penelitian tersebut lebih menekankan tentang pentingnya ketiga komponen yang menyusun SRI tersebut.

Pada penelitian ini, didapatkan bahwa dari ketiga komponen SRI (engagement in self-reflection, need for selfreflection dan insight) nilai skor rata-rata dari komponen yang paling mendekati skor rata-rata total SRI $(2,46)$ adalah komponen engagement in self-reflection yaitu 2,47. Hal ini menandakan bahwa komponen engagement for self-reflection dapat dianggap yang paling mewakili skala SRI. Walau tidak sepenuhnya sama, tapi dalam penelitian yang dilakukan oleh Grant ${ }^{6}$ disebutkan bahwa need for selfreflection dan engagement in selfreflection memuat faktorfaktor yang sama. Dengan demikian, kedua komponen tersebut seharusnya memiliki nilai yang tidak terlalu berbeda seperti yang terdapat dalam hasil penelitian ini.

Dalam penelitian Roberts \& Stark, ${ }^{3}$ dilakukan eksplorasi terhadap hubungan antara faktor-faktor SRI dengan variabel latar-belakang mahasiswa (umur, jenis kelamin, tingkatan dalam pendidikan serta gelar yang diperoleh sebelumnya) dan dengan respon mahasiswa terhadap kuesioner tentang profesionalisme. Hasil penelitian Roberts \& Stark menunjukkan bahwa mahasiswa lakilaki memiliki skor yang tinggi terhadap faktor insight dibandingkan mahasiswa perempuan ( $t$-test $\mathrm{p}=0,002)$, tapi tidak ada perbedaan dalam faktor engagement atau need for self-reflection $(p=0,007)$.

Hal tersebut berbeda dengan penelitian tentang SRI yang dilakukan oleh Grant dkk. ${ }^{11}$ Grant adalah peneliti awal yang mengembangkan skala SRI. Dalam penelitian yang dilakukan terhadap mahasiswa psikologi, ditemukan hasil bahwa tidak ada perbedaan yang bermakna antara laki-laki dan perempuan, baik pada skor selfreflection maupun pada skorinsight.

Hasil tersebut serupa dengan hasil penelitian ini. Meskipun terdapat perbedaan rata-rata skor SRI antara laki-laki dan perempuan, namun tidak didapatkan perbedaan yang bermakna $(p>0,05)$. Demikian juga dengan hasil yang didapatkan pada perbedaan rata-rata skor 
persepsi terhadap perilaku bertanggung-jawab, tidak ditemukan perbedaan antara laki-laki dan perempuan $(p=0,257)$.

Hal ini sedikit berbeda dengan hasil yang didapatkan pada penelitian Roberts \& Stark. ${ }^{3}$ Perbedaan lain yaitu bahwa analisis dalam penelitian ini dilakukan terhadap keseluruhan komponen SRI secara utuh, bukan terhadap masing-masing komponen penyusun SRI.

Penelitian yang dilakukan Jankowski dkk ${ }^{12}$ menunjukkan hasil yang berbeda. Secara keseluruhan, didapatkan nilai skala SRI yang lebih tinggi pada wanita baik pada pre-test maupun post-test pada metode experiential learning dalam CPE (Clinical Pastoral Education).

Walaupun bukan dalam konteks penelitian yang sama, sejumlah peneliti menemukan perbedaan gender terkait self-esteem secara keseluruhan. Demikian dituliskan oleh Ormrod ${ }^{13}$ dalam bukunya tentang psikologi pendidikan. Anak laki-laki memiliki persepsi diri yang lebih positif dibandingkan anak perempuan, terutama pada masa remaja. Secara rata-rata, dibandingkan anak laki-laki, anak perempuan lebih dominan memiliki perasaan bersalah, malu dan empati - emosi-emosi yang diasosiasikan dengan perilaku moral.

Berkaitan dengan tingkatan mahasiswa, pada penelitian ini tidak terdapat perbedaan yang bermakna dalam skor SRI pada berbagi fase akademik ( $p>0,05)$. Hal yang sama juga ditemukan dalam penelitian yang dilakukan oleh Roberts \& Stark, ${ }^{3}$ yaitu tidak ditemukan adanya peningkatan skor pada faktor komponen juga pada komponen insight sejalan dengan keempat fase program pendidikan. Persepsi mahasiswa terhadap perilaku bertanggung-jawab juga tidak menunjukkan perbedaan yang bermakna berdasarkan tingkat dalam fase akademik ( $p>0,05)$.

Lowe $\mathrm{dkk}^{14}$ dalam hasil penelitiannya menunjukkan bahwa refleksi dipengaruhi oleh berbagai faktor yang berhubungan dengan kursus yang diikuti, konteks praktik, dan individu. Hal yang senada juga diuraikan dalam penelitian Jankowski $\mathrm{dkk}^{12}$ bahwa skor self-reflection rata-rata menurun secara signifikan sejalan dengan waktu. Dalam penelitian tersebut, responden yang dinilai adalah responden yang sama saat sebelum dan sesudah CPE dilakukan (rancangan longitudinal study). Sedangkan dalam penelitian ini, rancangan yang digunakan adalah cross- sectional study. Demikian juga dengan penelitian yang dilakukan oleh Roberts \& Stark ${ }^{3}$. Kemungkinan hal tersebutlah yang menyebabkan perbedaan yang ada dengan kedua hasil penelitian sebelumnya tentang pengaruh tingkat dalam fase akademik.

Dalam penelitian ini selanjutnya ditemukan bahwa ada perbedaan yang bermakna antara responden asal SMU Makassar dan luar Makasar dalam skor SRI, tetapi tidak dalam persepsi terhadap perilaku bertanggung-jawab. Responden asal SMU luar Makassar umumnya berasal dari daerah kabupaten tingkat II atau provinsi lain di kawasan Timur Indonesia. Peneliti tidak menemukan penelitian tentang SRI atau pun perilaku bertanggungjawab yang menghubungkan dengan latar belakang asal sekolah, namun ada beberapa penelitian terkait pembelajar yang berasal dari kota dan luar kota (rural dan urban).

Waters $\mathrm{dkk}^{15}$ melakukan penelitian kohort (2002-2004) yang membandingkan mahasiswa kedokteran yang belajar dalam settingkota dan desa (metode pembelajaran dan kurikulum yang diberikan sama). Ditemukan bahwa di tahun 2002 tidak terdapat perbedaan yang signifikan dalam prestasi akademik antara mahasiswa yang belajar dalam setting kota dan desa secara umum namun penelitian kohort pada tahun 2003 ditemukan perbedaan signifikan dengan hasil skor tertinggi pada mahasiswa yang belajar dalam setting desa di akhir tahun ke-4 untuk keterampilan pemeriksaan klinis $(\mathrm{p}=0,025)$. Sedangkan pada tahun 2004, skor mahasiswa yang berlatar belakang desa di tahun ke-3 lebih tinggi pada rotasi kesehatan jiwa $(p=0,038)$ dan lebih rendah pada rotasi pengobatan medis $(\mathrm{p}=0,037)$.

Penelitian lain yang dilakukan berkaitan dengan siswa SMU yang berlatar belakang kota dan desa adalah penelitian yang dilakukan oleh McCracken dan Barcinas. ${ }^{16}$ Dalam penelitian tersebut ditemukan bahwa pelajar desa $(2,64)$ memiliki nilai IPK yang lebih tinggi dibanding pelajar kota $(2,54)$. Namun tidak ada perbedaan signifikan dalam jumlah aktivitas ektrakurikuler yang mereka ikuti. Dari segi jumlah pelajar kota lebih banyak siswanya, juga lebih lebih banyak guru, staf administrasi dan staf pendukung, dengan lebih banyak kursus dan aktivitas ekstra-kurikuler. Artinya kehidupan pelajar kota lebih banyak interaksi yang terjadi. Dilanjutkan dalam kesimpulan penelitian 
tersebut, bahwa pelajar di desa karakteristik latar belakangnya bersifat lebih homogen sedangkan pelajar kota memiliki campuran latar belakang suku dan kebudayaan yang lebih besar. Kurangnya kesempatan pelajar desa untuk berinteraksi dengan orang-orang dengan latar-belakang yang berbeda dapat menjadi faktor yang membatasi perkembangan pendidikan dan sosialnya.

Peneliti berkesimpulan bahwa faktor latar belakang sosial lebih kompleks pada mahasiswa asal kota dibandingkan dengan mahasiswa asal luar kota. Dari hasil penelitian ini penulis menyimpulkan bahwa faktor latar belakang sosial memberi pengaruh pada nilai SRI. Kehidupan di kota yang lebih kompleks dapat membuat seseorang lebih memperhitungkan keberadaan dirinya, dan membuat seseorang dapat melihat diri dan lingkungan sekitarnya secara nyata. Akan tetapi perbedaan latarbelakang asal sekolah tersebut ternyata tidak memberi pengaruh pada persepsi mahasiswa terhadap perilaku tanggung-jawab.

Masalah tanggung-jawab dalam konteks individual berkaitan dengan konteks teologis. ${ }^{9}$ Manusia sebagai makhluk individual artinya manusia harus bertanggungjawab terhadap dirinya (keseimbangan jasmani dan rohani) dan harus bertanggung-jawab terhadap Tuhannya (sebagai penciptanya). Tanggung-jawab manusia terhadap dirinya akan lebih kuat intensitasnya apabila dia memiliki kesadaran yang lebih mendalam. Tanggungjawab manusia terhadap dirinya juga muncul sebagai akibat keyakinannya terhadap suatu nilai.

Berkaitan dengan latar belakang suku, hasil dalam penelitian ini menunjukkan bahwa tidak ada perbedaan yang bermakna dalam skor SRI di antara ketiga kelompok suku yang ada. Demikian juga hasil yang didapat pada skor persepsi. Tilaar ${ }^{17}$ menguraikan tentang etnisitas dalam tulisannya pada bagian tentang identitas anak bangsa bahwa Indonesia yang memiliki tidak kurang dari 726 suku dengan adat-istiadat masing-masing dan tingkat perkembangannya yang berbeda-beda dikatakan belum mempunyai data yang rinci mengenai perkembangan identitas anak pada masing-masing suku tersebut. Kajian-kajian akademik masih didasarkan pada hasil penelitian dan akumulasi pedagogik dari dunia Barat. Tapi jika bersandarkan pada kajian akademik dari dunia Barat, beberapa hasil penelitian menunjukkan adanya perbedaan berdasarkan karakteristik etnis dalam hal budaya belajar masing-masing etnis tertentu. ${ }^{13}$

Berkaitan dengan latar belakang pendidikan orang tua dan pekerjaan orang tua, terdapat perbedaan antara kedua variabel baik terhadap skor SRI maupun terhadap skor persepsi. Penulis tidak menemukan penelitian yang mengaitkan nilai SRI atau persepsi perilaku profesional dengan latar belakang pendidikan dan pekerjaan orangtua. Namun dalam penelitian ini, ditemukan bahwa terdapat perbedaan yang bermakna $(p=0,018)$ pada responden berdasarkan latar belakang pekerjaan ayah pada skor persepsi terhadap perilaku bertanggung-jawab, tetapi tidak pada skor SRI. Hal ini menunjukkan bahwa keluarga memiliki peran dalam pengembangan perilaku profesional, meskipun umum diketahui bahwa dalam dunia keluarga, ${ }^{17}$ sosok "ibu" merupakan sosok yang terpenting sejalan dengan perkembangan emosi dan kognitif serta fisik seorang anak hingga dalam ke dunia yang lebih luas.

Hasil analisis hubungan antara level SRI dan persepsi mahasiswa terhadap perilaku bertanggung-jawab ditemukan adanya hubungan yang bermakna, bahwa rendahnya level SRI seiring dengan rendahnya persepsi terhadap perilaku bertanggung-jawab tersebut. Hal ini sesuai dengan teori yang disampaikan oleh Grant $\mathrm{dkk}^{11}$ bahwa seseorang yang mengedepankan selfreflection akan memunculkan pandangan baru terhadap pengalaman, melahirkan perubahan sikap dan kesiapan untuk mengaplikasikan sebuah komitmen, yang pada akhirnya akan berbuah pada perilaku yang profesional.

Sejalan dengan yang dikemukakan oleh Ginsburg \& Lingard ${ }^{18}$ tentang keuntungan mengeksplorasi refleksi sebagai suatu cara untuk memahami perilaku profesional mahasiswa. Disebutkan bahwa refleksi memberikan pemahaman terhadap sikap pembelajar tentang profesi kedokteran dan perasaan mereka dalam mengembangkan identitas dalam berhubungan dengan komunitas barunya serta harapannya. Mengeksplorasi alasan di balik perilaku sangat penting karena tindakan yang dipilih oleh seseorang tidak nampak secara pasti dalam hasil yang diamati.

Quirk ${ }^{19}$ sekali lagi menegaskan tentang bagaimana selfreflection dan insight berhubungan dengan profesionalisme. Profesionalisme yang dapat direalisasikan dalam 
hubungan dokter-pasien melalui kemanusiawian, komitmen terhadap kejujuran yang bersifat kompeten dan intelektual, kemampuan self-assessment yang tepat serta adanya rasa tanggung-jawab. Termasuk di dalamnya, bagaimana berhubungan dengan teman kelompok dan supervisor dan bagaimana seharusnya merespon suatu supervisi.

\section{KESIMPULAN}

Berdasarkan hasil penelitian, maka dapat disimpulkan bahwa secara umum self-reflection and insight (SRI) Mahasiswa Kedokteran FK UMI masih rendah yang ditunjukkan dengan skor SRI rata-rata 2,46 (dari maksimal skor). Rendahnya skor tersebut diikuti dengan rendahnya skor persepsi mahasiswa terhadap perilaku profesional (dalam hal ini perilaku bertanggung-jawab) dengan skor rata-rata 2,25.

Dalam analisis yang lebih lanjut, ditemukan bahwa rendahnya skor tersebut bervariasi berdasarkan karakteristik mahasiswa yang diukur dalam penelitian ini, walaupun sebagian besar perbedaan tersebut tidak bermakna. Di antara keseluruhan karakteristik tersebut, perbedaan bermakna skor SRI ditemukan pada variabel asal SMU responden dengan skor rata-rata lebih tinggi pada responden asal SMU di Makasar. Sedangkan pada skor persepsi ditemukan perbedaan bermakna pada variabel pekerjaan ayah dengan skor rata-rata lebih tinggi pada responden dengan kategori pekerjaan lain ayah (yaitu kategori pekerjaan ayah selain PNS dan profesional).

\section{SARAN}

Bagi institusi: menciptakan lingkungan yang kondusif bagi mahasiswa untuk dapat mengenali dan mengembangkan self-reflection dan insight-nya, mendukung proses internalisasi dan pembelajaran tentang perilaku profesional sejak awal pendidikan, melibatkan seluruh sivitas akademik dalam penciptaan suasana tersebut.

Bagi penelitian selanjutnya: menggali lebih jauh tentang self-reflection dan insight serta melakukan studi longitudinal untuk melihat perkembangan SRI pada mahasiswa.

Bagi mahasiswa: mengenali SRI masing-masing dengan baik dan berusaha untuk mengembangkan perilaku profesional sehingga menjadi bagian dari kehidupannya kelak

\section{DAFTAR PUSTAKA}

1. Konsil Kedokteran Indonesia. Standar kompetensi dokter Indonesia. Jakarta: Konsil Kedokteran Indonesia; 2006.

2. Papadakis MA, Hodgson CS, Teherani A, Kohatsu ND. Unprofessional behaviour in medical school is associated with subsequent disciplinary action. State Medical Board. Acad. Med. 2004; 79: 224-49.

3. Roberts C, Stark P. Readiness for self-directed change in professional behavior: factorial validation of the Self-reflection and Insight Scale. Blackwell Publishing Ltd. Medical Education. 2008; 42:1054-63.

4. Hays RB, Jolly BC, Caldon LJM, McCrorie P, McAvoy PA, McManus IC, Rethans JJ. Is insight important? Measuring capacity to change performance. Med. Educ. 2002; 36: 965-71.

5. Stark P, Roberts C, Newble DI, Bax ND. Discovering professionalism through guided reflection. Med. Teach. 2006; 28: 25-31.

6. Grant AM, Franklin J, Langford P. The Self-reflection and Insight Scale: a new measure of private selfconscious-ness. Soc. Behav. Pers. 2002; 30: 821-36.

7. Cruess SR, Cruess RL. The Cognitive Base of Profesionalism. Teaching Medical Professionalism. Cambridge University Press; 2009.

8. National Board of Medical Examiners. Embedding professionalism in medical education: Assessment as a tool for implementation. Report from an Invitational Conference by the Assiciation of American Colleges and the National Board of Medical Examiners; 2002.

9. Widagdho D. Manusia dan tanggung-jawab. Ilmu Budaya Dasar. Ed. revisi. Jakarta: PT Bumi Aksara; 2010.

10. Yoyok. Penggolongan pekerjaan dalam proses identifikasi pasien di rumah sakit [Internet]. Informasi Rekam Medis dan Bidang Kesehatan, 2009. Available from: http://rekamkesehatan.wordpress.com/2009/ 02/21/penggolongan-pekerjaan-dalam-prosesidentifikasi-pasien-di-rumah-sakit/> [Accessed $14 \mathrm{Mei}$ 2013]

11. Grant AM. The impact of life coaching on goal attainment, metacognition and mental health. Soc Behav Pers. 2003; 31: 253-64.

12. Jankowski KRB, Vanderwerker LC, Murphy KM, Montonye M, Ross AM. Change in pastoral skills, emotional intelligence, self-reflection, and social desirabilityacross a unit of CPE. Journal of Health Care Chaplaincy. 2008;15: 132-48.

13. Ormrod JE. Keberagaman dalam perkembangan. Dalam: Rahmat, R. Ed. Psikologi Pendidikan, 
Membantu Siswa Tumbuh dan Berkembang. Jakarta: Erlangga; 2008.

14. Lowe M, Rapport S, Jaglal S, Macdonald G. The Role of Reflection in Implementing Learning from Continuing Education into Practice. Journal of Continuing Education in Health Professional. 2007; 27(3): 143-8.

15. Waters B, Hughes J, Forbes K, Wilkinson D. Comparative academic performance of medical students in rural and urban clinical settings. Medical Education. Blackwell Publishing [internet]. 2006. [Accessed 14 Mei 2013] Available from <http://www.ncbi.nlm.nih. gov/pubmed/16451238>.

16. McCracken JD, Barcinas JDT. Differences between rural and urban schools, student characteristics, and student aspiration in Ohio. Journal of Research in Rural Education [Internet]. 1991. [Cited 2013 May 14]. Available from:<www.jrre.psu.edu/articles/ v7,n2,p29-40,McCracken.pdf $>$.

17. Tilaar HAR. Proses pembentukan identitas bangsa, beberapa konsep pedagogik. Dalam: Mengindonesia, Etnisitas dan Identitas Bangsa Indonesia. Jakarta: PT Rineka Cipta. 2007.

18. Ginsburg S, Lingard L. Using reflection and rhetoric to understand professional behaviors. In: Stern, D.T. Ed. Measuring medical professionalism. Oxford University Press. 2006; 195-210.

19. Quirck M. Intuition and metacognition in medical education: professionalism. New York: Springer Publishing Company. 2006. 